\title{
The political (in) dependence of the judiciary in Cameroon: fact or fiction?
}

\author{
Gerard Emmanuel Kamdem Kamga a,b \\ ${ }^{a}$ Centre for Sexualities, Aids and Gender, University of Pretoria, Huis \& Haard Building, Private Bag X20, Office \\ 2-25, Hatfield 0028, UK; ${ }^{b}$ Free State Centre for Human Rights, University of the Free State, Bloemfontein, \\ South Africa
}

\section{ABSTRACT}

My main concern in this paper is to critically examine judicial deference to the executive within the context of Cameroon. I portray how authorities in the country purposely fail to invest the judiciary with substantial levels of independence. In so doing, I look at the nexus between the domineering executive entity and the prevailing Hobbesian conception of separation of powers according to which powers mutually divided destroy each other. My investigation revolves around the idea as to know whether it is possible to mitigate political intrusion and interference to judicial independence when such intrusion and interference have become inherent and consubstantial to the modus operandi of the political system itself. Various studies on judicial independence are available but the peculiarity of the current one is not about the extent or limitation to judicial independence but it questions whether this independence exists in the first place. The study further innovates by providing a theory based approach which is an attempt to capture judicial motivations as well as the rationale behind the erosion of the liberal political theory within the context of Cameroon.

\section{KEYWORDS}

Cameroon; separation of powers; constitutionalism; rule of law; authoritarianism

\section{Introduction}

The present paper critically examines the issue of the political (in) dependence of the judiciary within the context of Cameroon. As I will soon portray, matters pertaining to judicial independence such as security of tenure, financial security, immunity and institutional independence are simply left to the discretion of the executive power. During a recent solemn session of the Supreme Court of Cameroon, its former chairman Alexis Dipanda Mouelle referred to the independence of the judiciary as the gist of quality justice. He went on to identify some threats to the independence of judges namely, social pressure, financial pressure and especially political pressure. Dipanda was of the view that such pressures should be eradicated or mitigated by some mechanisms protecting judges. ${ }^{1}$ This speech was interesting except that it had nothing to do with the current reality. The fact is that judicial independence in Cameroon is not an issue. Courts regularly

CONTACT Gerard Emmanuel Kamdem Kamga gerard.emmanuel@gmail.com $\Theta$ Centre for Sexualities, Aids and Gender, University of Pretoria, Huis \& Haard Building, Private Bag X20, Office 2-25, Hatfield 0028, UK 
fail to act as an effective check when public authorities fail to comply with human rights and the rule of law. Since the colonial era and until today, judicial behaviour in the country has always been characterized by consistent deference to the executive office. In this study, I intend to show that the independence of the judiciary in Cameroon is not subject to any threat, for this independence is merely illusory. The judiciary has been institutionally grafted to the executive organ to the extent that what would have been a threat to the function (political interference) has been integrated within the state's apparatus and is now part of the legal praxis of the political system. Yet theoretically, the place of judicial power is central to the discourse of human rights, for the judiciary is usually perceived as a major feature regulating the political life of a nation by upholding the rule of law, ensuring accountability and check and balances. As observed by Tom Ginsburg

'one theory argues that the spread of judicial power is a reflection of a broader extension of rights consciousness around the globe. This theory focuses on the demand for judicial protection of fundamental rights. The achievements of the human rights movement, the shift toward markets that rely on notions of private property, and the spread of democracy all reflect the importance of ideas of fundamental rights. As rights consciousness has spread, the argument goes, so, too, does the importance of courts as the primary political actors with the mission to protect rights'. (Ginsburg 2003)

In the upcoming developments, I question whether it is possible to mitigate political intrusion and interference to judicial independence when such intrusion and interference have become inherent and consubstantial to the current modus operandi of the regime itself. Can one still consider as impediments to judicial independence, executive regulations and pressures on the judiciary that have become part and parcel of the system of governance in Cameroon? My concern is about the behaviour and place granted to judges in the legal and political system of Cameroon. My investigation is not about the extent or the limitation to judicial independence in the country but I question whether this indepedence actually exists in the first place. In so doing, I look at the domineering executive office, the central feature in the political system of Cameroon through the lens of Turkish justice. As depicted by Montesquieu, 'among the Turks, where the three powers are united in the person of the sultan, an atrocious despotism reigns' (Montesquieu 1989). It is crucial to understand that in constitutional democracy, an independent judiciary is the key element in safeguarding liberties and the rule of law. Montesquieu further observed that there is no liberty, if the judiciary is not separated from the legislative and executive. Generally, the meaning of independence is twofold:

One meaning-commonly invoked when considering the circumstances of the individual judge-is that a person is independent if she is able to take actions without fear of interference by another. In this sense, judicial independence is the idea that a judge ought to be free to decide the case before her without fear or anticipation of (illegitimate) punishments or rewards. Another meaning is perhaps less common in discussions surrounding judges, but applies naturally to courts and to the judicial system as a whole. We might think of a person or an institution as being dependent on another if the person or entity is unable to do its job without relying on some other institution or group. (Ferejohn 1999)

Judicial independence suggests the full responsibility of judges who, in performing their duties must be impartial and freed from any interference, pressure and threat of sanction. An independent judge is the one leading by example for the common good and whose decisions are not contaminated by political, religious or ideological considerations. Key 
features undermining judicial independence remain corruption, political pressures and interferences of various sorts. In Cameroon, after Section 37 (2) of the Constitution provides that 'Judicial power shall be exercised by the Supreme Court, Courts of Appeal and Tribunals', the subsequent sentence in the same section proclaims what seems to be the principle of judicial independence as follows:

The Judicial Power shall be independent of the executive and legislative powers. Magistrates of the bench shall, in the discharge of their duties, be governed only by the law and their conscience.

Yet this constitutional provision which is supposed to guarantee an independent judiciary is merely short-circuited by the subsequent paragraph, that is Section 37(3) which provides that the President of the Republic shall guarantee the independence of judicial power and appoint members of the bench and for the legal department. The above contra-dictory and incompatible paragraphs of section 37 support my submission regarding the illusory nature of judicial independence in Cameroon. It is evident that in this particular context, the judiciary is considered less as a major power than a minor institution which independence is guaranteed by the president.

The current deference of the judiciary to the executive in Cameroon accounts for the inefficiency of judges in performing their duties. Yet an independent judiciary in a constitutional democracy furthers certain important values: The first one is the high consideration of the rule of law that should be applicable to everyone irrespective of his/ her social economic and political status. This concern suggests the necessity of making sure that powerful people (particularly elected officials) cannot manipulate legal proceedings to their advantage. (Ferejohn 1999). The second purpose of an independent judiciary is that in a constitutional government only those laws that are constitutionally legitimate ought to be enforced, and courts must be able to do much of the work in deciding which laws survive this test. Thus, there is a need to ensure that courts are sufficiently independent to overturn congressional statutes that subvert these values (Ferejohn 1999). The aim of an independent judiciary as presented above remains ineffective within the context of Cameroon, for the country is yet to fully embrace the principles of the liberal political theory. The current institutional framework was designed not to enhance transparency, accountability, human rights and the rule of law but to achieve different goals. Borrowing from a study devoted to the politics of courts in authoritarian regimes, and based on some recent Cameroon experiences that I will soon portray, I am of the view that the following goals currently motivate the ruling class in preventing a genuine independence of the judiciary in the country:

Courts are used to (1) establish social control and sideline political opponents, (2) bolster a regime's claim to "legal" legitimacy, (3) strengthen administrative compliance within the state's own bureaucratic machinery and solve coordination problems among competing factions within the regime, (4) facilitate trade and investment, and (5) implement controversial policies so as to allow political distance from core elements of the regime. (Ginsburg and Moustafa 2008)

One of my main concerns in this study is also to account for judges' motivation and orientation in their functions. There are several studies on judicial independence available but in this particular one, I attempt to provide details clarifications as to understand what motivate judges to rule in one way or another. The point I am investigating here is 
whether judicial deference to the executive within the context of Cameroon is inherent to the institution or whether there is room for another alternative. As a starting point, I ask the following questions to frame the critical analysis on the political (in) dependence of the judiciary in Cameroon:

What is the status of the judiciary in Cameroon and to what extent does the judiciary (in) dependent from the politic?

Are there circumstances where authorities in Cameroon invest the judiciary with substantial levels of independence?

Is judicial deference to the Cameroon political elite a mere ideological sympathy and/or a lack of moral integrity?

To answer these interrogations, I firstly review the status of the judiciary in Cameroon before assessing the executive-court relations in time of peace as well as in crisis period. The study follows a legal and historical developments and stretches from 1960 to the present days. I further attempt to address judicial motivations through the assessment of the theory-based approach and provide suggestion(s) at the end.

\section{The status of the judiciary in Cameroon: from judicial authority to judicial authority}

I start this section by observing that there is no typing mistake in its title. The word 'status' is generally understood to be 'the legal position of a person, group or country'. Talking about the status of the judiciary in Cameroon is in fact referring to its place and function within the legal and political system. The current constitution of Cameroon introduces the judiciary as a power but as I am about to show, this judiciary is nothing but a mere and ordinary authority. Historically the first judiciary institution properly Cameroonian was created just a few days prior to the so-called independence of the state by ordinance $\mathrm{N}^{\circ}$ 59/86 of 17 December 1959 and decree $N^{\circ}$ 59/246 of 18 December 1959. Later in 1972 ordinance $\mathrm{N}^{\mathrm{o}} 72 / 04$ of 26 August 1972 was issued to reorganize judicial institutions within the state. This legislation was repealed in 2006 by law $N^{\circ} 2006 / 015$ of 29 December 2006 on judicial organization, amended and completed in 2011 by law $\mathrm{N}^{\mathrm{o}} 2011 / 027$. The previous constitutions of Cameroon, provided for only two powers namely, the Legislature and the President of the republic. Part 2 of the first constitution of 4 March 1960 was devoted to the 'legislative power' [Du pouvoir législatif] whereas part 3 focused on the 'President of the Republic' [Du président de la république]. The judiciary appeared in part 7 under the name 'Judicial authority' [De l'autorité judiciaire].

Similar construction was repeated in the subsequent constitution, that is law $\mathrm{N}^{\mathrm{o}} 61 / 24$ of 1 September 1961 instituting the Federal Republic of Cameroon. This constitution provided for only two powers including the president of the Federal Republic [Du président de la République Fédérale] ${ }^{2}$ and the Federal Legislature [Du législatif fédéral]. ${ }^{3}$ 'judicial authority' [De l'autorité judiciaire] was framed by Part 6. The constitution of 1 September 1961 also introduces a sort of hierarchy and importance among the powers within the state. For example whereas the constitution of 4 March 1960 characterized by a parliamentarian connotation dealt firstly with the legislature before any other power, ${ }^{4}$ all the subsequent constitutions opened on the 'president of the republic' ${ }^{5}$ It is worth noting that 
at the time, the concept of 'president of the republic' within the context of Cameroon was

significant, for it referred to what many constitutions around the world identify as 'executive power'. Emphasizing the expression 'president of the republic' instead of 'executive power' is a choice which since then has recurred and denotes the will of the successive law-makers to classify powers within the state according to a certain hierarchy and relevance. ${ }^{6}$ The presidentialist character of Cameroon institutions over the years has been very persistent so as to keeping emphasizing the expression 'president of the republic' instead of 'executive power'. On 2 June 1972 a new constitution was published but did not introduced any substantial change. The structure of powers across the state remained similar to that setup in the aftermath of 'independence' on 1 January 1960. Part 2 of the new constitution framed the 'President of the Republic' as part 3 dealt with the National Assembly. 'Judicial authority' once again was organized in part 5.

One of the main characteristics and common denominators of 'judicial authority' that is evident throughout the above mentioned three constitutions is the lack of

independence of the authority in charge of justice. This submission is confirmed by the fact that such 'independence' remains guaranteed by the president. As repeatedly provided by the subsequent constitutions, the president of the republic is the guarantor of the independence of the judicial authority and appoints judges. ${ }^{7}$ It is crucial to note that the concept of judicial authority within the context of Cameroon is not to be perceived as a special status where the bearers of the function perform their duties in an independent environment. In this political system, the raison d' être of judicial authority rests upon the president of the republic. The year 1996 was noticeable for the judiciary in the country, for the provisions of the constitution seemed to have raised the then judicial authority to the status of 'judicial power'. Law N 96/06 of 18 January 1996 'to amend the

constitution of 2 June 1972 ' formally refers for the first time to three powers within the state namely, the executive power, the legislative power, and the judicial power. The status of former judicial authority was then shifted and upgraded to that of 'a judicial power' ${ }^{8}$ In so doing the new constitution innovated by introducing two concepts in its lexicon including 'executive power' and 'judicial power'. With regards to the former, I have to point out that in the whole legal and historical architecture of Cameroon from the colonial era to the current one, the word 'executive power' [pouvoir exécutif] appears only twice. The first time was in the constitution of former federated state of the Southern Cameroons in the era of federalism. ${ }^{9}$ The word 'executive power' as provided for by this constitution did not include the president of the republic. It was basically allocated to the prime minister. The concept 'executive power' was introduced for the second time in the constitution of 18 January 1996 and this time, refers both to the president of the republic and the government supposedly led by a prime minister. ${ }^{10}$

Concerning the concept of 'judicial power' introduced by the current constitution, one would have legitimately expected a judiciary institution that has 'matured' and effectively became 'independent from the executive and legislative powers' following the wording of Section 37(2) of the constitution. Yet, the formulations 'judicial power' and 'independence' added together side by side were to remain a vain formula. After the reading of the first sentence of the section on 'judicial power', the institution is soon placed under the direct control of the president of the republic. In reality there has been no improvement between the status of former judicial authority and that of the brand new judicial power. Even though I have already quoted these provisions in the introductory section to this 
paper, I am citing them once again to make a proper account of my argument. The following are the provisions of Section 37(3) of the constitution:

The president of the republic shall guarantee the independence of judicial power. He shall appoint members of the bench and for the legal department.

The above provision is a repeat of Section 31 of the constitution of 2 June 1972, Section 32 of the constitution of 1 September 1961 and Section 41 of the constitution of 4 March 1960. It was observed that Section 37(2) and (3) of the current constitution are mutually incompatible and account for the insufficient elaboration of judicial power by the constituent. (Olinga 2006) Such observation is in line with the idea according to which the independence of the judiciary in Cameroon 'amounts to mere rhetoric given that the guarantee of that independence is effected through appointment of judges, their promotion and disciplining and these appointees can therefore not be independent of the President's i n fluence' (Fombad 1996). Indeed, the 'independence' proclaimed by the constitution in Section 37 (2) is soon trivialized by the subsequent paragraph which

reaffirms the tight control of the president over the state's structures. In light of the current constitutional provisions pertaining to judicial independence in Cameroon, it is my contention that there is no difference between the current 'judicial power' and former 'judicial authority'. This explains why I began my analysis of the current section of the paper by specifying that its title does not contain any typing mistake.

The notion of power has a peculiarity in terms of the relations among people, government, state and various entities. Behind the concept of Power, lies the idea of autonomy, independence and influence over the actions and decisions of others. The intuitive idea of power is 'something like this: A has power over B to the extent that he can get B to do something that B would not otherwise do' (Dahl 1957). Though being a particular and powerful phenomenon, the notion of power is common to contemporary societies. 'The word and its synonyms are everywhere embedded in the language of civilized peoples, often in subtly different ways: power, influence, control, pouvoir, puissance, Macht, Herrschaft, Gewalt, imperium, potestas, auctoritas, potentia, etc' (Dahl 1957). Connecting these developments to the context of Cameroon, there has been a failure of shifting from judicial authority to judicial power. The judiciary has no control over its functions, for the institution is under the complete influence of the executive office. Judicial authority at least institutionally, remains a mere authority deprived of autonomy, independence and influence not only over its own office but also over other state's entities and the society as whole. Resultantly, the independence of the judiciary in Cameroon is not an issue.

\section{Executive-court relations in time of peace: interference between political interests and judicial office}

In the current section, I provide focus on the mechanisms through which the political elite manipulates state's institutions to achieve judicial deference to the executive in Cameroon. Firstly, candidates to the magistracy are recruited following a national competitive examination among postgraduate law students. After two years in the National School of Administration and Magistracy (ENAM), they are appointed in various areas across the country as Auditeurs de justice following an order signed by members of executive bodies notably the minister of justice. By virtue of the provisions of Section 3 of the 
decree of 8 March 1995 on the statute of the magistracy, public prosecutors for instance are hierarchically subordinated to the minister of justice and keeper of the seals. As a matter of facts, this ministry is a branch of the executive office. The process of selection and appointment of judges already attests to a lack of independence of the judicial institution. The political dependence of the judiciary to the executive power is not implicit but clearly formalized and this explains why not only it is not to be considered as a genuine power, but also it conveys the idea that the principle of the separation of powers within the context of Cameroon is yet to be conceptualized. Instead, the 'judicial power' in in the country is close to a ministerial department and an anteroom of the executive body. Prior to the constitution of 18 January 1996 Augustin Kontchou Kouomegni, former Minister of Communication and government's spokesperson, unveiled the place and the nature of the judiciary in the legal architecture of Cameroon:

L'autorité judiciaire est une simple branche de l'administration publique et non un troisième pouvoir [...] L'autorité judiciaire dans ce contexte, n'a pas pour fonction, comme dans le constitutionnalisme classique, de garantir la séparation et l'équilibre des pouvoirs et partant la limitation des pouvoirs des gouvernants, mais un instrument du maintien de l'hégémonie administrative sur l'appareil de l'Etat. (Bigombe 1996)

The judicial authority is a mere branch of public administration and not a third power [...] Contrary to classical constitutionalism, the judicial authority in such context does not aim at fulfilling the separation and balance of powers and thereby the limitation of powers, but it is a tool of the administrative hegemony over the state apparatus. ${ }^{11}$

Judges' selection, career, appointment and promotion including the chairman of the Supreme Court are conditioned by presidential discretion.

Secondly, by virtue of the provisions of Section 1 of law $\mathrm{N}^{\mathrm{o}} 89 / 016$ of 28 July 1989, which amends law $\mathrm{N}^{\mathrm{o}} 82 / 14$ of 26 November 1982 on the organization and functioning of the Higher Judicial Council, the president of the republic is the chair of this Council with the minister of justice as the deputy chair. It is then barely conceivable how, under such a system, a judge might follow a path different from that of his hierarchy, that is the president. Under Ahmadou Ahidjo, the first president of Cameroon, judges were well aware of their state of indebtedness to the president and did not hesitate to openly acknowledge their allegiance to him. In December 2004, Ananga Beyina Onesiphore, retired Colonel of Gendarmerie and military judge observed how following media interview, judges were not shy about being subjugated to the president:

Je n'ai pas de comptes à vous rendre. Je ne vous dois rien. C'est au Président de la république seul que je dois le poste que j'occupe. J'y serai tant qu'il le voudra. Si je réponds à vos questions, c'est parce que je veux. Vous n'avez aucun droit, aucun pouvoir sur moi. (Tsala 2011)

I am not accountable to you. I owe you nothing. I owe my position only to the President of the republic. I will keep it as long as it suits him. If I answer to your questions it is because I am willing to do so. You have no right, no power over me. ${ }^{12}$

The above quote attests to the fact that in Cameroon, the 'judicial power', due to its mode of functioning and organization, is a dismemberment of the administration, and not a third power as intended. Within this framework the independence of the judiciary is therefore not an issue, for judges' perception of their functions is very narrow to the extent that what remain of their powers is simply and gently surrendered to the president. I am of the 
view that the political dependence of the judiciary within the state has moved from the realm of tyranny to that of normality.

Thirdly, in terms of legal norms protecting judges, another crucial point is the fact that in Cameroon the authority in charge of appointing judges (in this case the President of the republic), is also invested with the power to dismiss them. This is likely to happen in case judges fail to comply with presidential 'instructions' in performing their duties. Yet until 1961, members of the judiciary enjoyed a relatively independent status owing to the then constitutional protection. Section 41 of the constitution of 4 March 1960 prevented judges from being dismissed. This relevant provision was removed in 1961 from the second constitution and is still ignored by the current one. Similar provision was available until 1995 when decree $\mathrm{N}^{\mathrm{o}}$ 95/048 on 8 March 1995 pertaining to the statute of the magistracy prohibited judges from being transferred without their consent. This requirement was removed in 1995 following the amendment to the bill on the magistracy. The current situation allows for the possibility whereby a judge who disagrees with the political elite may be transferred to be declined jurisdiction over a trial unfavourable to the government. This is what occurred in the case of retired Justice Nyo Wakai \& 172 others $v$ The People. ${ }^{13}$ In 1992 following the controversial presidential elections and the growing contestations on the streets, 173 applicants were arrested in Bamenda, northwest region of Cameroon after the implementation of a de facto state of emergency in the area. After investigations, the High Court of Bamenda decided against charging the applicants but instead ordered their release. The ministry of justice, executive branch ignored the release order and transferred the suspects from the northwest region to the capital Yaounde in the Centre region. I have to mention at this level of the analysis that there co-exist in Cameroon's legal architecture the French civil law, the British common law and the customary law. The common law system is applicable within the English speaking area of the country (northwest and southwest regions) while the civil law system is in force in the remaining French speaking portion of 8 regions. This composite system is derived from the legacy of the French and British administrations which took over the then Kamerun (German spelling). Indeed, toward the end of the first world war, the country which until then was a German colony became a United Nations trust territory. Contrary to what most people including foreign nationals, the media and even some Cameroonians themselves were led to believe, from a technical and legal perspectives, Cameroon (along with Togo) has never been a formal colony of neither France nor Britain but a United Nations trust territory which at the time was placed under their respective administration by the United Nations. This explains why at the peak of the war of independence against France, the Union des Populations $d u$ Cameroun (UPC) a nationalist movement led by the iconic Ruben Um Nyobe fought to achieve independence and reunification of Kamerun which was literally the raison d' être of the movement. The movement always used the German spelling 'Kamerun' to refer to the original territory which at the time was controlled by the Germans. Having (very briefly) clarified that, I am now resuming my analysis. The ministerial decision to transfer non convicted people from a specific judicial sphere to a different one attests for the scale of executive interference and despise of the judiciary in the country. This conduct gives a glimpse of how administrative officials in Cameroon make a mockery of the principle of independence of the judiciary and there is really no relief to administrative whims and caprices (Nkumbe 2011). The event also comforts the following view about other mechanisms for keeping judges in line: 
The capacity within the circuits to assign and reassign cases, and to initiate disciplinary proceedings against individual judges, works to keep individual judges responsive to their duties in the constitutional system. Such mechanisms are controversial in that they create a method, short of impeachment, by which judges may effectively be prohibited from hearing cases. (Ferejohn 1999)

Alluding to the independence of the judiciary in Cameroon amounts to turning toward a realm of fiction. The close control of the executive over the judicial proceedings remains one of the key elements of survival of the regime. In its Country Reports on Human Rights Practices for 2017, the U.S. State Department observed about the Cameroon judiciary the following:

The court system is subordinate to the Ministry of Justice. The constitution designates the president as 'first magistrate,' thus 'chief' of the judiciary making him the legal arbiter of any sanctions against the judiciary.

When a judge cannot be transferred, it is the case itself which can be transferred from one judge to another, from one judicial sphere to a different one as portrayed in the above case of retired justice Nyo Wakai.

Fourthly, judges in the country do not enjoy the opportunity to perform their duties in a truly independent manner for various reasons including a wide range of sanctions at the disposal of the president and other members of the executive; sanctions hanging up over their head like a sword of Damocles. These sanctions provided for by chapter 8 of the decree of 1995 entitled 'discipline' include among others, warning, reprimand, striking off the judicial advancement list, downgrade, suspension and removal. ${ }^{14}$ It is within this context that on 6 July 2017 through a presidential decree, President Paul Biya dismissed judge Pascal Magnaguemabe from the judicial body of Cameroon on the ground of extortion. The sanction was decreed and that was it. Sanctions may be issued according to the case either by a presidential order or by the minister of justice, in other words by the executive entity. In addition to sanctions by 'presidential order', judges are also subject to 'other sanctions', those pronounced by 'presidential decree' following the provisions of section $47(3)$ of the decree of 1995 . Yet, there is neither a demarcation line nor a specific criterion between sanctions issued through a presidential order and those issued through a presidential decree. I want to highlight the fact that this range of pre-existing sanctions against members of the judiciary by the executive blatantly violates the provisions of Section 126 of the Cameroon Penal Penal Code entitled 'executive and judiciary reciprocally'. This section deemed to bolster judicial independence in the country provides for sanctions for up to 5 years in prison for 'whoever being the representative of the executive authority, issues any order or prohibition to any court'. The wide range of sanctions that judges are subject to within the context of Cameroon contributes to judicial capitulation which is at some point understandable given that 'the first and most obvious possible explanation for judicial capitulation to authoritarian rule in any country is that authoritarian leaders manipulated the courts, through purges, threats, or jurisdictional restrictions' (Hilbink 2007).

Fifthly, the complete absence of an independent judiciary in Cameroon owes much not only to institutional factors but also to regime-related factor as there is no separation of powers and check and balances. A different study on the judiciary which is a lesson from South Africa on how institutional factors can be used to bolster judicial 
independence was made available recently. ${ }^{15}$ The court-executive relations in Cameroon are similar to those of superior and subordinate, master and slave. Most of the time judges operate as a tool to achieving social and political control to the profit of the executive branch. In 1987 for instance, following unrests in Cameroon, some journalists were arrested. In an interview on state television on 19 February 1987 president Biya said 'I know that some journalists have been arrested [...] Firstly I have to mention that this arrest was for the purpose of investigation. The investigation being completed, I have given order to free them'. The president's request to release angry journalists was not to be confused with a presiden al pardon. It was not only the reaffirmation of the presidential dominance over the institutional framework but also a reminder that despite the apparent separation of powers, he remained the only one to order, reassign and redefine the role of everyone. Except the use of courts as a tool for social and political control, the judiciary in the country also contributes to sideline political opponents and challengers to the ruling class. Some recorded cases attest to the collision between political interests and judicial functions. In 1962 during Ahidjo's tenure, former Prime Minister Andre-Marie Mbida and his friends, challengers to the then president were sentenced to 36 months in prison and a fine of 250.000 Fcfa for each of them by the court of appeal in Yaounde. They had criticized the regime and were arrested on the ground of Ordinance $\mathrm{N}^{\circ} 62 / 18 / \mathrm{OF}$ of 12 March 1962 for suppressing subversion. However, at the Supreme Court, the case was handed over to Mr. Starter a French judge who nullified the judgment owing to various irregularities. President Ahidjo who had been informed of such ruling which was about to be published, requested and obtained the entire file and evidence in the presidential palace. Resultantly, the condemned were compelled to spend 3 years in prison. A few times later, the president issued an ordinance stating that sentences passed by his military courts could not be subject to any sort of appeal. This was understandable in the sense that in an environment where judicial independence amounts to a pure fiction 'the objective would be to leave the courts with only routine, nonthreatening decisions to make, preserving their utility, but reserving the important and threatening litigation for decision by more controllable agencies, e.g. military courts' (Hilbink 2007). A few decades following Ahidjo's interference in judicial functions, similar manoeuvre recurred under president Biya regime. Until 1990 the multiparty system was de facto banned in the country but the impact of the democratization's wind over Africa was to produce a considerable impact. In that period some members of the civil society and political leaders including Yondo Black, lawyer and former chairman of the Cameroon bar, Ekane Anicet and Jean Michel Tekam, political leaders attempted to launch their own political parties. They were arrested on the ground of the ordinance of 12 March 1962 suppressing subversion and sentenced by a military tribunal to 3 years in prison. Sidelining political opponents to the benefit of the executive or ruling class has become almost a traditional role of the judiciary in Cameroon. In the same vein, going back to 1992 following the presidential elections, Paul Biya the then and current president was declared victor under controversial circumstances. The Supreme Court despite acknowledging frauds and various irregularities that compromised the elections, declared it incompetence to rule on them. This situation was another blow to the idea of judicial independence, for 'the conduct of the Supreme Court in this matter revealed that it cannot be trusted because it has proven to be an ally of the executive'

(Fombad 1999). In Cameroon, interference between political interests and judicial office 
remains the trademark of the executive-court relations whether in time of peace or in time of crisis.

\section{Executive-court relations in time of crisis: political immunity and judicial deference to the executive}

In this section I examine the situations whereby the judiciary is expressly denied jurisdiction over some categories of political acts. It is the case of Acts of State (also known as ouster clauses or Acts of government) which amount to acts invested with political motive. The peculiarity of such acts is their immunity and as such they are subject neither to parliamentarian approval nor to judicial review. I have provided in a previous analysis, details developments concerning the Acts of State. ${ }^{16}$ The prototype of Acts of state within the context of Cameroon is the presidential act declaring a state of emergency and so called state of siege which is not subject to any sort of contestation. The rationale and praxis behind the concept of Act of State is as follows: in his prerogative to enforce a state of emergency and so called a state of siege, the president in Cameroon behave like if the executive power was the only structure to rule the state (which is literally true). Historically the jurisprudence on the theory of Acts of State during emergency regimes was formally established in 1962 by the French Conseil d'Etat in the case of Rubin de Servens. Following the Algiers Putsch in April 1961, French president Charles de Gaulle enforced section 16 of the constitution on the state of exception which granted him full powers. The enforcement of Section 16 lasted until 29 September 1961. On 3 May, even though the threat against the national integrity of France was over months ago, de Gaulle set up a special military tribunal for the trial of people who threatened the republic and infringed the discipline of the army. 10 officers of this army including Mr. Rubin de Servens were sentenced by the military court. They then appeared before the Conseil d'Etat to challenge the presidential decision of the creation of a military tribunal on the ground of abuse of power. The judge argues about the presidential decision to implement section 16 of the constitution as follows:

Cette décision présente le caractère d'un acte de gouvernement dont il n'appartient pas au conseil d'état d'apprécier ni la légalité, ni de contrôler la durée d'application. ${ }^{17}$

This decision appears to be an act of state of which the council of state is not entitled to rule on neither the legality nor the control of the duration of implementation. ${ }^{18}$

Later, judicial decisions similar to that of the case of Rubin de Servens soon emerged in Cameroon where the jurisprudence of the Council of State is part of the legacy of French imperialism in the country. As a result, the formal prohibition to the Cameroon judiciary to rule over some category of political acts was repeatedly codified by the law maker and soon became an exonerating mechanism, that is a sort of absolution for the executive to reign and rule without limit. It is within this framework that section 22 of ordinance $\mathrm{N}^{\mathrm{o}} 72 / 6$ of 26 August 1972 on the organization of Supreme Court reads:

No court or tribunal is entitled to rule on acts of states.

In 1979 the criteria of an Act of state and the prohibition to the judiciary to rule over it were clearly expressed in the case of Kouang Guillaume Charles vs the State of Cameroon. ${ }^{19}$ 
In this case, the administrative court rules that 'one refer to an act of state when it is about a political matter of an exclusive governmental concern' ${ }^{20}$ The court went on to unveil a whole typology of Acts of State that include among others those pertaining to the diplomatic relationships of the state with foreign countries, the governmental acts issued in its relationships with Parliament (promulgation of laws, convening or ending of parliamentary sessions) and presidential act convening the Electoral College as well as the presidential act declaring a state of emergency and state of exception. ${ }^{21}$ The incompetence of judges to rule over the Acts of State in Cameroon was reaffirmed by section 4 of law $\mathrm{N}^{\mathrm{o}}$ 2006/022 of 29 December 2006 relating to the organization of the administrative courts which expressly states that 'no court is entitled to rule on Acts of State'. With regard to the presidential act convening the Electoral College for instance, in 1992 amidst the deteriorating atmosphere characterized by political troubles and instability across the country, a presidential decree setting up an agenda for early presidential elections was issued. The judicial action before the court aiming at nullifying the decree was unsuccessful as judges qualified the presidential decree to be an Act of State above their competence. Similar conclusion recurred in 1995 when the minister of youth and sports dissolved the Cameroon Football Federation (FECAFOOT). In replying to a request of explanation from FIFA (International Federation of Football Association), the minister argued that the decision to dissolve the federation was an Act of State and therefore not subject to accountability (Kamto 1995).

Based on these developments, it is my submission that that an Act of State within the context of Cameroon is nothing but a device allowing the executive power to place itself beyond the law, bypass judicial review and deny accountability. Since the amendment of the constitution in April 2008, the lack of an independent judiciary in the country has been reaffirmed through the expansion and constitutionnalization of the notion of Act of State. Indeed, the irresponsibility of the president of the republic during and after his term was clearly entrenched in the new section 53(3) as follows:

Acts committed by the President of the Republic in pursuance of articles 5, 8, 9 and $10^{22}$ above shall be covered by immunity and he shall not be accountable for them after the exercise of his functions.

The Act of State amounts to the idea of raison d'état and as such remains a veil of irresponsibility and non-accountability of the president during and after his term. In such a case judicial independence clearly amounts to nothing but a fiction.

\section{Understanding judicial motivations: the theory based approach}

In the previous sections I have portrayed how the collision between political interests and judicial functions were purposefully organized by the political elite whether in crisis period or in time of peace. In this section I try to examine and explain judicial motivations and allegiance to the executive power in the country. To set the scene of this section, it is worth quoting the following interrogation from Gretchen Helmke:

When a judge decides a case in favour of the government, is it because he or she simply agrees with the government's position in the case? Or does his or her decision instead reflect a fear of reprisal were he or she to stand up to the government? Conversely, when a judge decides cases against the government, is it because he or she truly disagrees with the government's position? Or is it for some other reason? (Gretchen 2005) 
The following answer to judicial complicity in non-democratic states was provided by the legal theory explanation in these terms:

The judges' professional understandings of the nature of law and adjudication rendered them unwilling or unable to hold regime leaders legally accountable for repressive acts and policies. The most common culprit is legal positivism, which analysts blame for leading judges to believe that their role is passive and mechanical; that is, that their function is to apply the letter of the law without concern for the outcomes of their decisions or for the preservation of general. (Hilbink 2007)

It is observed that judges rule against the rulers not because they enjoy independence in a conventional sense but because they fear being punished by the government's successors (Gretchen 2005). It is this ability to behave strategically according to certain circumstances and political factors that is currently referred to as the 'strategic defection' (Gretchen 2005). Three types of factors are relevant in explaining judges' behaviour and motivations. The first one is about judges as policy seekers. This factor is driven solely by judges' desire to bring the law closest to their ideal point given that if the situation involves the judge's own removal, he or she might lose the opportunity to influence the system (Gretchen 2005). Accordingly, a judge who remains in office may, temporarily, have to alter his or her behaviour to accommodate political realities, but leaves open the possibility to make an impact on policy if and when the political context is more favourable. A contrario, a judge who loses his or her position also loose the opportunity to influence the system. Thus, as long as this type of judge has a sufficiently high discount rate for the future and some expectation that the power of the future government may eventually wane, judges who care about policy will be adverse to sanctions (Gretchen 2005).

The concept of judges as policy seekers is hardly applicable to the case of Cameroon, for the issue is not about the future or incumbent government. In a country where after nearly 60 years of so called independence with only two recorded presidents, the regime is more inclined to a presidential dictatorship than a constitutional democracy. Due to a poor institutional framework surrounding their office, judges do not have the necessary means to influence the political system and guarantee human rights and the rule of law. In the second section of this paper, I have portrayed how the judiciary in Cameroon was institutionally designed to remain a judicial authority (instead of a genuine judicial power) controlled and managed by the executive office for its own sake.

The second factor behind judicial motivations is professionalism. In this scenario, judges seek to maintain their own personal reputation and that of their institution. Although such goals may ultimately be seen as a means to either career advancement or policy making, professionally oriented judges would appear to be the least interested in maintaining their posts or ensuring that their decisions stand and are thus the least likely to engage in defection (Gretchen 2005).

Professionals motivated judges are likely to be seen in a genuine democratic society rooted in separation of powers and check and balances. This is yet to happen in Cameroon where the system shares more characteristics with authoritarian and totalitarian states. Facing the harsh reality, the behaviour of Cameroon judges appears to be more determined by their career and nothing else.

The third factor that may influence judges' behaviour is the career, explained as follows: 
The careerist is motivated not by public-regarding goals, but rather by personal career advancement. For the careerist, the costs of removal depend solely on the subsequent career opportunities available to him or her. (Gretchen 2005)

Looking at the state of the current judiciary in Cameroon and the various experiences portrayed in the previous developments, I am of the view that what matter to judges is their career or more precisely their personal interests. The rationale behind judicial deference to the executive stemmed from the apprehension that standing or ruling against political authorities may result in misfortune of various kinds. In Cameroon, a country dominated by rampant poverty, corruption and growing unemployment, where the state remains the greatest employer, no one wants to risk losing his or her job by antagonizing the regime. It was observed that 'for example, in economically volatile settings where state employment ensures judges a steady job and a host of licit (and sometimes illicit) perks, careerists are likely to be averse to making decisions that risk removal' (Gretchen 2005). This also fully explains the fact that 'when judges are handpicked by regime leaders, or cowed by fear for their personal safety or economic security, one cannot expect significant resistance' (Hilbink 2007). Another attempt to understand judges' behaviour was unveiled by critical legal theorists who argue that courts always serve the interests of the powerful, whether under democratic or authoritarian regimes (Hilbink 2007). The reason is that in various countries, judges do tend to come from elite backgrounds, and are thus socialized in similar family, community, and educational institutions, their approach to interpreting law and administering justice may well be a function, conscious or not, of class interests (Hilbink 2007).

In light of the above analysis, judicial independence in Cameroon appears closer to fiction than reality. I am now providing accounts as to know why these mechanics of rendering the principle of judicial independence meaningless have worked so far. In fact, this was achieved by the regime that successfully discarded basic principles of legal and constitutional principles that characterize the liberal political doctrine. Despite the fact that the constitution names three powers, such powers are hold by a single entity, that is the president of the republic. One can see that the classic formulation of the principle of separation of powers as proclaimed by thinkers such as Locke and Montesquieu was nullified; principle grounded on the idea that the three key and separate governmental functions, the legislative function, the executive function, and the judicial function should be performed by three distinct entities including the legislature, the executive and the judiciary. Five main reasons have historically been given for requiring that the legislative, executive, and judicial functions should not be exercised by the same people: the rule of law, accountability, common interest, efficiency, and balancing of interests (Gwyn 1965). The conception of separation of powers in Cameroon appears therefore to be slightly different; even thought it was already accepted among the founding generation as an established touchstone of constitutional legitimacy (Waldron 2013). The current situation in Cameroon led me to reflect on Vile's submission according to which the separation of powers 'represents an area of political thought in which there has been an extraordinary confusion in the definition and use of terms' (Vile 1998). The fact that the principle of separation of powers remain questionable within the context of Cameroon is an indication of the nexus between the judiciary institution itself and the very nature of the political system in the country. In the Federalist $N^{\circ} 47$ James Madison points out that 'the accumulation of all powers, 
legislative, executive, and judiciary, in the same hands, whether of one, a few, or many, and whether hereditary, self-appointed, or elective, may justly be pronounced the very definition of tyranny' (Goldman 2008). I reached the conclusion that in Cameroon, the concept of an independent judiciary as conceptualized by the doctrine of liberalism cannot work not because powers cannot be divided but because 'powers mutually divided destroy each other'. It is therefore the Hobbesian theory that is applicable within the state, a theory that posits that the various powers of government are indivisible, incommunicable, and inseparable (Hobbes 1651). These powers are effectively in place, but they are all blurred and united within the hands of the executive. Since it is no longer possible to distinguish them, it will be more rational to admit that the principle of separation of powers along with its adjacent Principles such as the division of power and checks and balances are yet to be conceptualized in Cameroon's institutional schemes.

\section{Conclusion}

In this paper, I argued about the issue of the political (in) dependence of the judiciary within the context of Cameroon. Based on the legal and historical analysis I have provided in the study, it appeared that the idea of an independent judiciary in the country is more aligned with fiction than fact. I have unpacked how whether in time of peace or in crisis period, the judiciary in the country is institutionally and purposely designed to be controlled by the executive entity. Not only the status of the judiciary remains that of a judicial authority, but also the systematic interference between political interests and judicial functions has led to a complete obliteration of the judicial entity by the executive body. In addition, the formal political immunity of the president derived from the Acts of State supports my contention that if the executive power in Cameroon was to interfere with the judiciary, it would be similar to colluding with its own shadow. All the powers are available but the principle of separation of powers does not apply given that it is the Hobbesian conception of the confusion of powers that is enforced instead of the principle of liberal political theory.

The president in Cameroon symbolizes the picture of Turkish justice I referred to in the introductory section to this paper, that is a sultan who incarnates the three powers and who reign authoritatively without any restriction. What is striking, is the perspicacity and consistency with which Cameroon authorities have over the years successfully managed to empty the substance of the principles dear to the doctrine of liberalism and constitutional democracy. The skilful manipulations of the 'rules of the game' to the exclusive profit of the president since 1960 resulted in an alchemic mixture where the techniques of authoritarianism successfully cohabit side by side with the principles of democracy within a single document namely, the constitution.

In sum, I believe we are left with a very few options to remedy the issue of an independent judiciary in Cameroon. In my view, there is only one suggestion in an attempt to completely reconsider the concept of judicial independence within the state which is the imperative to rethink the nature of the political system of Cameroon. The truth is that there is no room for judicial independence in a presidentialist regime. Presidentialism is a typology of authoritarianism and it is such a typology that is currently in place in Cameroon. Paying close attention as to how to bring about a completely radical transformation of institutions is in my sense the key and with regard to the methods and means to bring about this change, that is a different kettle of fish. 


\section{Notes}

1. “Cour Suprême: L'indépendance de la justice au cour de la rentrée solennelle." http:// cameroon-info.net/stories/0,26213,@,cour-supreme-l-independance-de-la-justice-au-c-urde-la-rentree-solennelle.html. Accessed 27 March 2017.

2. See part 3 of law No 61/24 of 1 September 1961.

3. See part 4 of law No 61/24 of 1 September 1961.

4. See part 2 on the legislature and part 3 on the president of the republic.

5. Part 3 of the Federal Constitution of Cameroon of 1 September 1961 and part 2 of the constitution of 2 June 1972.

6. Part 3 on the President of the Federal republic and Part 4 on the federal legislature of the constitution of 1 September 1961; Part 2 on the president of republic and Part 3 on the National Assembly of the constitution of 2 June 1972. Part 2 on the executive power and part 3 on the legislative power of the constitution of 18 January 1996.

7. Section 31 of the constitution of the United Republic of Cameroon of 2 June 1972, section 32 of law No-61/24 of 1 September 1961 and section 41 of the constitution of 4 March 1960.

8. Part 4 of aw $\mathrm{N}^{\circ} 96 / 06$ of 18 January 1996 to amend the Constitution of 2 June 1972.

9. Chapitre 3, le pouvoir exécutif, loi No 61-LW-1 du 26 Octobre 1961 portant Constitution de l'Etat Fédéré du Cameroun Occidental.

10. Part 2 of law $\mathrm{N}^{\mathrm{o}} 96 / 06$ of 18 January 1996 to amend the Constitution of 2 June 1972.

11. [own translation].

12. [own translation].

13. Judgment $\mathrm{N}^{\mathrm{o}} \mathrm{HCB} / 19 / \mathrm{CRM} / 921$ of 23 December 1992 retired Justice Nyo Wakai \& 172 Others v. People. High Court of Mezam Judicial Division, Bamenda.

14. Section 47 of Decree $\mathrm{N}^{\circ}$ 95/048 of 8 March 1995 on the Statute of Magistracy.

15. Djoyou Kamga S. and Kamdem Kamga G. Independent Judiciary: lessons from South Africa in Wahab Egbewole (Eds) Judicial Independence in Africa, Wildly, Simmonds \& Hill Publish-ing, December 2017.

16. G.E. Starting the emergency process: some reflections on presidential prerogatives in South Africa and Cameroon in time of turmoil. VRUe/Law and Politics in Africa, Asia, Latin America 2016 Vol. 49 (1).

17. Conseil d'Etat 2 Mars 1962 Rubin de Servens.

18. [Own translation].

19. Kouang Guillaume Charles contre Etat du Cameroun jugement No 66 ADD/CS/CA du 31 Mai 1979.

20. Ibid.

21. Ibid.

22. These articles refer to the presidential prerogatives in general, such as the power of appointment (art. 10), declaration of a state of emergency and a state of siege (art. 9), representativeness (art. 8) and general policy of the nation (art.5).

\section{Disclosure statement}

No potential conflict of interest was reported by the author.

\section{References}

Bigombe, P. 1996. "Emergence et consolidation des tendances constitutionnelles au Cameroun (1990-1195)." In la réforme constitutionnelle du 18 janvier 1996 au Cameroun: aspects juridiques et politiques (1996), sous la direction de Melone S, Minkoa S et Sindjoun, 8-19. Yaounde: Fondation Friedrich Ebert/Association Africaine de science politique (section Camerounaise, Grap). 
Conseil d'Etat 2 Mars 1962 Rubin de Servens.

Constitution of the United Republic of Cameroon of 2 June 1972.

Dahl, R. 1957. “The Concept of Power." Behavioral Science 2 (3): 201-215.

Decree $\mathrm{N}^{\mathrm{o}}$ 95/048 of 8 March 1995 on the Statute of Magistracy.

Federal Constitution of Cameroon of 1 September 1961.

Ferejohn, J. 1999. “Independent Judges, Dependent Judiciary: Explaining Judicial Independence.” Southern California Law Review 72: 353-384.

Fombad, C. 1996. "Judicial Power in Cameroon's Amended Constitution of 18 January 1996." Lesotho Law Journal 9 (2): 1-11. Fombad, C. 1999. "Cameroon's Emergency Powers: A Recipe for (Un)constitutional Dictatorship?”Journal of African Law 48 (1): 62-81.

Ginsburg, T. 2003. Judicial Review in New Democracies Constitutional Courts in Asian

Cases. Cambridge: Cambridge University Press.

Ginsburg, T., and T. Moustafa. 2008. "The Functions of Courts in Authoritarian Politics.” In Rule by Law the Politics of Courts in Authoritarian Regimes, edited by T. Ginsburg, and T. Moustafa, 1-22. Cambridge: Cambridge University Press.

Gretchen, H. 2005. Courts Under Constraints Judges, Generals, and Presidents in Argentina. Cambridge: Cambridge University Press.

Gwyn, W. B. 1965. The Meaning of the Separation of Powers. An Analysis of the Doctrine from Its Origin to the Adoption of the United States Constitution. New Orleans: Tulane University.

Hamilton, A., J. Jay, and J. Madison. 2011. The Federalist. Auckland: The Floating Press.

Hilbink, L. 2007. Judges Beyond Politics in Democracy and Dictatorship Lessons from Chile. Cambridge: Cambridge University Press.

Hobbes's Leviathan. Reprinted from the edition of 1651 Clarendon: Oxford.

Judgment $N^{o}$ HCB/19/CRM/921 of 23 December 1992 retired Justice Nyo Wakai \& 172 others v. People. High Court of Mezam Judicial Division, Bamenda.

Kamto, M. 1995. “Le contentieux électoral au Cameroun." Lex Lata 20 (3): 3-18.

Kouang Guillaume Charles contre Etat du Cameroun jugement $N^{\circ} 66$ ADD/CS/CA du 31 Mai 1979.

Law N $\mathrm{N}^{\circ} 96 / 06$ of 18 January 1996 to amend the Constitution of 2 June 1972.

Loi $\mathrm{N}^{\mathrm{o}}$ 61-LW-1 du 26 Octobre 1961 portant Constitution de l'Etat Fédéré du Cameroun Occidental.

Montesquieu, C. 1989. The Spirit of the Laws 157. Translated and edited by Anne M. Cohler et al. Cambridge: Cambridge University Press.

Nkumbe, N. 2011. "The Effectiveness of Domestic Complaint Mechanisms in the Protection of Human Rights in Cameroon." Cameroon Journal on Democracy and Human Rights 5 (2): 21-55.

Olinga, D. 2006. La Constitution de la République du Cameroun. Yaounde: Les éditions terre africaines, presses de l'UCAC.

Tsala, C. 2011. Les détenus politiques au Cameroun de 1958 à 1991, thèse de doctorat. Yaounde: Université de Yaoundé I.

Vile, M. J. C. 1998. Constitutionalism and the Separation of Powers. 2nd ed. Indianapolis: Liberty Fund.

Waldron, J. 2013. "Separation of Powers in Thought and Practice?" Boston College Law Review 54 (2): 433-468. 